UDC 678: 613.6.02

DOI: 10.21668/health.risk/2020.1.06.eng

\title{
ASSESSMENT OF OCCUPATIONAL HEALTH RISK FOR WORKERS EMPLOYED AT CONTEMPORARY RUBBER PRODUCTION
}

\author{
E.T. Valeeva, L.K. Karimova, R.R. Galimova, N.A. Muldasheva, A.A. Distanova \\ Ufa Research Institute of Occupational Health and Human Ecology, 94 Stepana Kuvykina Str., Ufa, 450106, \\ Russian Federation
}

The paper dwells on the results obtained in assessing occupational health risk for workers employed at rubber production; the assessment was based on examining both a priori and a posteriori parameters. It was shown that workers were exposed to a set of factors related to working environment and labor process including hazardous chemicals, in-plant noise, adverse microclimate, as well as physical overloads. Chemical factor played the leading role as there were various chemicals in working area air such as benzene in concentrations equal to 1.2-3.0 MPC (maximum single concentration amounted to 4 MPC); dichloromethane in concentrations equal to 0.2-1.5 MPC average monthly (maximum single ones equal to 2 MPC). Overall working conditions assessment for workers with different occupations employed at rubber production belonged to 3.2 hazard category. Workers who glued parts of articles together ran high risks of occupational diseases; risks were average for spreading machine operators and vulcanizers. Total occupational diseases index amounted to 0.83 for workers who glued articles and to 0.80 for spreading machine operators and vulcanizers and it meant that occupational risk was high. We also revealed that certain diseases were occupationally induced and the dependence was significant; it was true for segmental disorders in the vegetative nervous system with sensitivity failure in hands for gluing workers (RR - 10.3, CI =95\%, EF-90\%), musculoskeletal system diseases $(R R-2.5, C I=95 \%, E F-55 \%)$, and skin and subcutaneous tissue diseases for spreading machine operators and vulcanizers $(R R-2.6, C I=95 \%, E F-61 \%)$. We ranked occupations as per related occupational health risks and revealed that workers who glued articles had the highest integral occupational risk assessment.

Occupational risk assessment gave grounds for developing a risk-oriented program that included priorities and ways to prevent damage to health of workers employed at rubber production such as managerial and medical and prevention activities as well as social support and protection.

Key words: occupational risk, health, workers, hazardous occupational factors, working conditions, rubber production, occupational diseases, occupationally induced diseases, prevention.

Three are certain branches in the economy of the Russian Federation that determine its scientific, technical, and economic development; chemical industry is a leading one among such brunches. Among other productions, it includes rubber and plastic products manufacturing. Chemical productions usually involve emitting multi-component chemical admixtures into working area air, as it is well-known in occupational hygiene, and it creates risks for workers' health [1-4].

Rubber products (module pneumatic constructions or constructions used in rescue work, for example) are usually made of rubber cloths and such manufacturing requires formed materials, engineering constructions, tanks for storing oil, glues, and sealants. Cloth rubberizing is a basic process in rubber production and it involves applying glues that are a solution of rubber mixtures in solvents (petrol, dichloromethane, benzine, etc.).

Workers that glue parts of engineering constructions together (hereinafter called gluers) and spreading machine operators (hereinafter called spreading operators) are two basic

(C) Valeeva E.T., Karimova L.K., Galimova R.R., Muldasheva N.A., Distanova A.A., 2020

El'viraT. Valeeva - Doctor of Medical Sciences, Head of the Department for Workers' Health Protection (e-mail: oozr@mail.ru; tel.: +7 (347) 255-30-57; ORCID: https://orcid.org/000-0002-9146-5625).

Liliya K. Karimova - Doctor of Medical Sciences, Professor, Chief Researcher (e-mail: iao_karimova@rambler.ru; tel.: +7 (347) 255-57-21; ORCID: https://orcid.org/0000-0002-9859-8260).

RasimaR. Galimova - Candidate of Medical Sciences, Senior researcher at the Department for Workers' Health Protection (e-mail: rasima75@mail.ru; tel.: +7 (347) 255-30-57; ORCID: https://orcid.org/0000-0002-4658-545X).

NadezhdaA. Muldasheva - Junior researcher at the Department for Occupational Hygiene and Physiology (e-mail: muldasheva51@gmail.com; tel.: +7 (347) 255-57-21; ORCID: https://orcid.org/0000-0002-3518-3519).

AlbinaA. Distanova - Allergologist-immunologist at the Department for Occupational Allergology and Immune Rehabilitation (e-mail: f_albina@rambler.ru; tel.: +7 (347) 255-57-08); ORCID: https://orcid.org/0000-0003-4249-2288). 
occupational groups in workshops where rubber cloths and glues are manufactured. Gluers are mostly women; spreading operators, men. Overall assessment of working conditions reveals that working conditions for gluers correspond to 3.1 hazard category (the chemical factor being the leading one); working conditions for spreading operators, 3.3 hazard category (the leading factor is labor hardness).

All technical equipment applied in rubber production is placed in enclosed space. A whole set of hazardous occupational factors influences workers' health; these factors are related to industrial environment and labor processes and are potentially harmful. They occur due to high temperatures in workshops and open processes; use of toxic multi-component rubber mixtures and glues; production equipment that generates a lot of noise. According to official statistics, occupational morbidity among workers employed in chemical industry has been higher than on average in the country over recent years $(1.17$ cases per 10,000 workers in the RF; 2.16 cases per 10,000 workers in manufacturing); it calls for assessing working conditions and predicting damage to workers' health basing on procedures for occupational risks assessment.

Prevention of occupational and workrelated diseases as well as workers' health preservation is a vital task the occupational medicine is to solve [5-9].

Our research goal was to assess occupational risks of health disorders among workers employed at rubber production via examining a priori and a posteriori parameters in order to give grounds for a risk-oriented prevention program.

Data and methods. We analyzed and assessed occupational risks according to Guide
2.2.1766-03 ${ }^{1}$ using hygienic and medical and biological parameters $[10,11]$.

Violation of hygienic standards (concentrations exceeding MPC) was assessed in accordance with the Guide 2.2.2006- $05^{2}$. To assess a priori health risks, we took data obtained via the Specific assessment of working conditions $(\mathrm{SAWC})^{3}$, industrial control procedures accomplished according to SR 1.1.1058-014, and targeted scientific research as well [12]. We assessed occupational risks for specific occupational groups with the same working conditions and used it a basis for assessing group occupational risks.

We examined health of 370 workers employed at rubber production; 210 out of them were female gluers $(84.5 \%)$; and the rest were male spreading operators $(15.5 \%)$.

Workers were distributed as per their age and working experience length; the results were as follows: $17.7 \%$ had 5-10 years of working experience; $59.6 \%, 11-15$ years; $22.7 \%$, 15 years or longer. $46.0 \%$ workers were 39-49 years old; $24.0 \%, 30-38$ years old; $21.0 \%, 50$ years and older; $9.0 \%, 20-29$ years old. Our reference group was made up of 130 inspectors from the quality control department; they were comparable with workers from the examined occupational groups in terms of their age and working experience.

A posteriori risk assessment was performed as per medical and biological parameters, notably occupational and work-related diseases.

We calculated intensive parameters of occupational morbidity for a specific occupational group taking into account a number of first detected occupational diseases per 10,000 workers with the same occupation. Rubber production involves combined exposure to

${ }^{1} \mathrm{P}$ 2.2.1766-03. The Guide on assessment of occupational risks for workers' health. Organizational and methodical grounds, principles, and assessment criteria. KonsultantPlus. Available at: https://consultant.ru/document/cons_doc_LAW_130907/ (02.10.2018)

${ }^{2}$ P 2.2.2006-05. The Guide on hygienic assessment of factors related to working environment and labor process. KonsultantPlus. Available at: http://www.consultant.ru/document/cons doc LAW 85537/ (15.02.2018).

${ }^{3}$ On Approval of Procedure for conducting a special assessment of working conditions, Classifier of adverse and (or) hazardous production factors, reporting form on a specific assessment of working conditions and instructions how to fill it in: The Order issued by the RF Ministry for labor and Social Protection on January 24, 2014 No. 33n. KonsultantPlus. Available at: http://www.consultant.ru/document/cons_doc_LAW_158398/(10.04.2018).

${ }^{4}$ SR 1.1.1058-01. How to organize and perform industrial control over adhering to sanitary rules and accomplishing sanitary and anti-epidemic (preventive) activities. KonsultantPlus. Available at: http://www.consultant.ru/document/cons_doc_LAW_33872/ $(10.04 .2018)$ 
hazardous occupational factors; given that, it is necessary to assess not only each occupational disease separately but their combination as well. In such cases, to assess occupational risks, we took an integral parameter for occupational diseases frequency and gravity, a so called occupational diseases index (Iocc) that was a an inverse value of risk category $(\mathrm{Cr})$ and hardness category $(\mathrm{Ch})$; it was an onenumber index that combined $\mathrm{Cr}$ and $\mathrm{Ch}$ parameters as a probable risk level [13, 14].

Besides, we assessed how strong a causeand-effect relation was for health disorders and occupational factors.

We assessed an extent to what diseases were occupational or work-related depending on relative risk (RR), $95 \%$ confidence interval (CI), and etiological fraction (EF).

Ultimate assessment of occupational risks that could cause health disorders in workers employed at rubber production was performed taking into account hygienic and medical and biological parameters basing on occupational risk categories; those categories took into account classes of working conditions, occupational morbidity, and urgency of activities aimed at reducing risks. Urgency of such activities was determined on the basis of occupational risk categories. Assessment results were communicated to workers, employers, and other concerned parties.

Our research focused on assessing occupational risks for health of workers employed at rubber production and dealing with either materials rubberizing or products assembling.

Results and discussion. We analyzed our research results and revealed that workers employed at contemporary chemical productions were exposed to a set of occupational factors and labor process; it included toxicants (predominantly solvents such as benzine or dichloromethane), intense in-plant noise, adverse microclimate, and physical overloads as well.
Workers from basic occupational groups (gluers, spreading operators, and vulcanizers) were exposed to chemical factors, namely benzine in concentrations equal to 1.2-4.0 MPC and dichloromethane, 0.2-1.5 MPC taken as per average monthly values; maximum single exposure to benzine could reach $4 \mathrm{MPC}$; dichloromethane, 2 MPC. Both these substances produce acute targeted neuro-, hepato-, and gematotoxic effects as well as irritant ones ${ }^{2,5}[15-19]$.

Besides, maximum permissible noise levels and microclimate parameters (so called (HIS or heat stress index) at workplaces of spreading operators and vulcanizers corresponded to hazard category 3.1-3.2.

Workers with basic occupations had to lift and move weights during their work shifts; they were exposed to local physical loads (weights lifted and moved manually ( $\mathrm{kg}$ ); (single) lifting and moving a weight followed by other work tasks (up to 2 times per hour, hazard category 3.1); body bending (forced posture at an angle exceeding $30^{\circ}$ ), (times per a shift)), hazard category 3.2); all the above substantiated assessing such working conditions as hazardous (3.1-3.2) according to Guide 2.2.2006-0 $5^{2}$.

Ultimate assessment of working conditions for workers with basic occupations employed at the examined production allowed ranking them as hazard category 3.2 (Table 1).

Exposure to hazardous occupational factors and factors related to labor process caused occupational and work-related diseases.

Chronic intoxications were mostly detected among gluers (30\%) who dealt with making large engineering constructions and were exposed to combined effects produced by a mix of solvents in concentrations which were 2-4 times higher than MPC; they also occurred among spreading operators $(7.5 \%)$. Clinical signs of solvent-induced intoxication included disorders in the vegetative nervous system (VNS) as per segmental type with initially occurring vegetative-sensory disorders in hands.

${ }^{5}$ HS 2.2.5.3532-18 Maximum permissible concentrations (MPC) of hazardous substances in working area air. KonsultantPlus. Available at: http://www.consultant.ru/document/cons_doc_LAW_296440/ (24.01.2018). 
Occupational factors and occupational risks occurring at rubber production

\begin{tabular}{|c|c|c|c|c|}
\hline \multicolumn{2}{|c|}{ Occupational factor } & Spreading operator & Vulcanizer & Gluer \\
\hline \multirow{2}{*}{$\begin{array}{l}\text { Chemical, benzine, higher } \\
\text { than MPC }\end{array}$} & $\mathrm{C}_{\mathrm{sm}}$ & 3.6 & 2.6 & 4,0 \\
\hline & $\mathrm{C}_{\mathrm{av} . \mathrm{s}}$ & 1.6 & 1.2 & $1,2-3,0$ \\
\hline \multicolumn{2}{|l|}{ Dichloromethane, $\mathrm{C}_{\mathrm{av} . \mathrm{s}}$} & 0,2 & 0.4 & $1.2-1.5$ \\
\hline \multicolumn{2}{|l|}{$\mathrm{C}_{\mathrm{s.m} .}$} & 0,3 & 0.5 & 2 \\
\hline \multicolumn{2}{|l|}{ Working conditions category } & 3.1 & 3.1 & 3.2 \\
\hline \multicolumn{2}{|l|}{ Noise, Higher than MPL, dB } & By 5 & By 5 & Not detected \\
\hline \multicolumn{2}{|l|}{ Working conditions category } & 3.1 & 3.1 & 2.0 \\
\hline \multicolumn{2}{|c|}{ Microclimate (increased HSI, ${ }^{\circ} \mathrm{C}$ ) } & By 0.4 & By 1.2 & Not detected \\
\hline \multicolumn{2}{|l|}{ Working conditions category } & 3.1 & 3.2 & 2.0 \\
\hline \multicolumn{2}{|l|}{ Labor process hardness } & 3.2 & 3.2 & 3.1 \\
\hline \multicolumn{2}{|c|}{ Overall working conditions assessment } & 3.2 . & 3.2 . & 3.2 . \\
\hline \multicolumn{2}{|l|}{ Risk category } & Average & Average & Average \\
\hline
\end{tabular}

Note:

Cav.s. means average shift concentration;

Cms maximum single concentration.

Occupational diseases caused by physical overloads occurred as a rule under working conditions belonging to hazard category 3.2 as per labor process hardness. Occupational diseases with predominant damage to the vegetative nervous system and musculoskeletal system were diagnosed in $28.6 \%$ cases; they were hand polyneuropathy, facioscapulohumeral periathrosis, epicondylitis, and radiculopathy. Occupational sensorineural hearing loss was diagnosed in $2.2 \%$ cases.
Occupational risk parameters, depending on risk category and occupational diseases gravity, indicate that gluers run high risks of occupational diseases; spreading operators and vulcanizers, average risks. Overall occupational diseases index that took into account each occupational disease amounted to 0.83 for gluers and to 0.8 for spreading operators and vulcanizers and it allowed ranking occupational risks as high (Table 2). We detected that occupational diseases frequency and gravity depended on working conditions category.

Table 2

Occupational risk categories for workers employed at rubber production depending on occupational morbidity index (OMI)

\begin{tabular}{|c|c|c|c|c|c|}
\hline Occupation & Nosology & $\mathrm{C}_{\mathrm{r}}$ * & $\mathrm{D}_{\mathrm{g}}{ }^{*}$ & OM index* & Risk category \\
\hline \multirow{5}{*}{$\begin{array}{l}\text { Spreading operator, } \\
\text { vulcanizer }\end{array}$} & $\begin{array}{l}\text { facioscapulohumeral periathrosis without } \\
\text { functional disorders }\end{array}$ & 2 & 3 & 0.16 & average \\
\hline & radiculopathy without functional disorders & 2 & 3 & 0.16 & average \\
\hline & initial epicondylitis & 2 & 3 & 0.16 & average \\
\hline & hand polyneuropathy & 2 & 3 & 0.16 & average \\
\hline & sensorineural hearing loss & 2 & 3 & 0.16 & average \\
\hline Overall OM index & & & & 0.80 & \\
\hline \multirow[t]{2}{*}{ Gluer } & $\begin{array}{l}\text { mild chronic intoxication with a mix of } \\
\text { organic solvents (benzene, dichloromethane) }\end{array}$ & 1 & 2 & 0.52 & $\begin{array}{l}\text { extremely } \\
\text { high }\end{array}$ \\
\hline & hand polyneuropathy & 1 & 3 & 0.33 & high \\
\hline Overall OM index & & & & 0.85 & \\
\hline
\end{tabular}

Note:

* $-\mathrm{C}_{\mathrm{r}}$ and $\mathrm{D}_{\mathrm{g}}$ mean risk category and (occupational) disease gravity;

OMI means occupational morbidity index. 
Chronic non-infectious diseases that were the most frequently diagnosed in workers employed at rubber production included disorders in the vegetative nervous system as per segmental type; musculoskeletal system diseases; skin and subcutaneous tissue inflammations occurring due to skin micro-injuries; as well as biliary dyskinesia, and primary hypertension.

Having assessed an extent to which the diagnosed diseases were occupationally induced, we revealed that it was high for disorders in the vegetative nervous system as per segmental type with sensory disorders in hands among gluers (RR-10.3, 95 \% CI, EF-90 \%); musculoskeletal system diseases (lumbodynia) (RR -2.5, $95 \% \mathrm{CI}, \mathrm{EF}-55 \%$ ), and skin and subcutaneous tissue diseases among spreading operators and vulcanizers (RR -2.6, $95 \% \mathrm{CI}$, EF- $61 \%$ ) (Table 3).

Complex clinical and hygienic research gave grounds for ranking occupations as per occupational risks of health disorders taking into account for basic criteria: working conditions; occupational morbidity; a share of people who had signs of occupational disorders; an extent to which chronic non-communicable diseases were occupationally induced.

The highest integral assessment of occupational health risks was determined for gluers. Results obtained in assessing health of workers employed at rubber production as per medical and biological parameters were adjusted with overall assessment of working conditions (Table 4).

Table 3

An extent to which diseases occurring in workers employed at rubber production are occupationally induced

\begin{tabular}{|c|c|c|c|c|c|}
\hline Occupation & $\begin{array}{c}\text { Leading } \\
\text { hazardous factor, } \\
\text { working condi- } \\
\text { tions category }\end{array}$ & Nosology & $\mathrm{RR}$ & $\mathrm{EF}, \%$ & Extent \\
\hline Spreading operator & \multirow{2}{*}{$\begin{array}{l}\text { labor hardness } \\
(3.2)\end{array}$} & musculoskeletal system diseases & 2.2 & 55 & high \\
\hline Vulcanizer & & skin and subcutaneous tissue diseases & 2.6 & 61 & high \\
\hline \multirow{2}{*}{ Gluer } & \multirow{2}{*}{$\begin{array}{l}\text { chemical } \\
(3.2)\end{array}$} & $\begin{array}{l}\text { disorders in the vegetative nervous } \\
\text { system as per segmental type }\end{array}$ & 10.3 & 90 & $\begin{array}{c}\text { almost } \\
\text { completely }\end{array}$ \\
\hline & & biliary dyskinesia & 1.8 & 44 & average \\
\hline
\end{tabular}

Note:

RR means relative risk;

EF means etiological fraction.

Table 4

Integral assessment of occupational risks for workers employed at rubber production

\begin{tabular}{|c|c|c|c|c|c|c|c|c|c|}
\hline \multirow{3}{*}{ 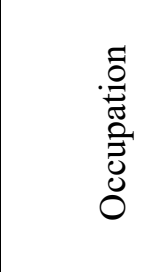 } & \multicolumn{2}{|c|}{ A priori risk } & \multicolumn{5}{|c|}{ A posteriori risk } & \multirow{3}{*}{ 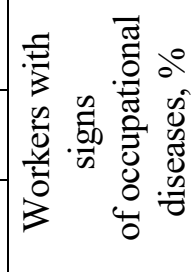 } & \multirow{3}{*}{ 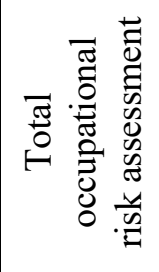 } \\
\hline & \multirow{2}{*}{ 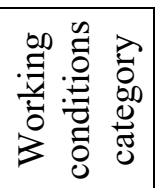 } & \multirow{2}{*}{ 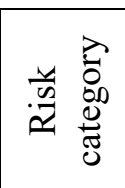 } & \multirow{2}{*}{ 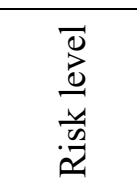 } & \multirow{2}{*}{ 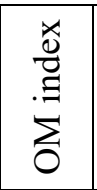 } & \multirow{2}{*}{ 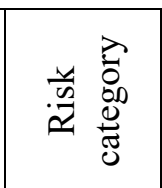 } & \multicolumn{2}{|c|}{$\begin{array}{l}\text { Occupational condi- } \\
\text { tionality of diseases }\end{array}$} & & \\
\hline & & & & & & $\mathrm{RR}$ & Extent & & \\
\hline Gluer & 3.2 & average & $\begin{array}{l}\text { above } \\
\text { average }\end{array}$ & 0.5 & $\begin{array}{c}\text { extremely } \\
\text { high }\end{array}$ & $4.9-7.6$ & $\begin{array}{l}\text { extremely } \\
\text { high }\end{array}$ & & $\begin{array}{c}\text { extreme } \\
\text { high }\end{array}$ \\
\hline $\begin{array}{l}\text { preading } \\
\text { perator, } \\
\text { ulcanizer }\end{array}$ & 3.2 & average & $\begin{array}{l}\text { above } \\
\text { average }\end{array}$ & 0.33 & high & $2.5-3.9$ & high & 24.3 & his \\
\hline
\end{tabular}

Note:

RR means relative risk;

$\%_{0}$ is given per 10,000 workers. 
High occupational risks made it necessary to develop a risk-oriented program that included priority strategies and procedures for preventing damage to workers' health (managerial medical and preventive activities and social protection) (Figure 1). The program was then tested at a plant that manufactured rubber engineering products and implemented at corporate and individual levels. The corporate level covered providing safe working conditions based on applying technological charts for uninterrupted flow-production, wide use of automated lines, supply-and-exhaust mechanic ventilation with rational air inflow that allowed reducing benzine and dichloromethane concentrations in working area air. The individual level involved preventing complex exposure to solvents via using efficient individual protection means including specific clothing and footwear, benzine-resistant gloves, and skin protective creams.

Medical examinations play a significant role within prevention activities aimed at preventing occupational and work-related diseases [20]. When workers are hired, they are to have a preliminary medical examination; when they perform their work functions, they should have periodical medical examinations (PME). Medical examinations are performed according to requirements fixed by the RF Ministry for Public Healthcare and Social Development issued on April 12, 2011 No. 302n ${ }^{6}$. An obligatory condition for performing periodical medical examinations is that workers with long work experience are to be examined at a center for occupational pathology every five years; should initial signs of any occupational pathology be detected in a worker, he or she should have annual periodical examinations at such centers.
It seems rational to divide workers employed at rubber production into three groups for periodical examinations with determining necessary prevention activities for each group.

The $1^{\text {st }}$ group includes healthy workers. They are to have periodical medical examinations.

The $2^{\text {nd }}$ group includes those workers who ran risks of occupational diseases and are to have annual medical examinations and improve their health at sanatoriums once a year.

The $3^{\text {rd }}$ group includes:

a) workers suffering from occupational diseases. They are to visit medical establishments more frequently and if a repeated examination is required, they are to visit a center for occupational pathologies and have an outpatient or in-patient hospital treatment;

b) people with work-related diseases. They are to visit medical establishments and improve their health in sanatoriums; in case of necessity they are to have an out-patient or inpatient hospital treatment.

It is very important to provide timely and rational employment for workers suffering form occupational and chronic noncommunicable diseases who can't perform their work tasks under hazardous working conditions; it is a key component in a system of medical and preventive, social, and rehabilitation activities. Medical examinations and recommended treatment as well as health-improving procedures are to be regulated according to a health group a worker belongs to; these health groups are determined as per results obtained via PME according to the Order by the RF Public Healthcare Ministry issued on October 26, 2017 No. $869 n^{7}$.

\footnotetext{
${ }^{6}$ On Approval of the list of adverse and (or) hazardous occupational factors and work tasks that require obligatory preliminary and periodical medical examinations of workers and the procedure for performing obligatory preliminary and periodical medical examinations of workers employed at workplaces with hard work and adverse and (or) hazardous working conditions: The Order by the RF Ministry for Public Healthcare and Social Development issued on April 12, 2011 No. 302. KonsultantPlus. Available at: http://www.consultant.ru/document/cons_doc_LAW_120902/ (24.01.2018).

${ }^{7}$ On Approval of the procedure for medical examinations of specific adult population groups: The Order by the RF Ministry for Public Healthcare and Social Development issued on October 26, 2017 No. 869n. KonsultantPlus. Available at: http://www.consultant.ru/document/cons_doc_LAW_284986/(24.01.2018).
} 


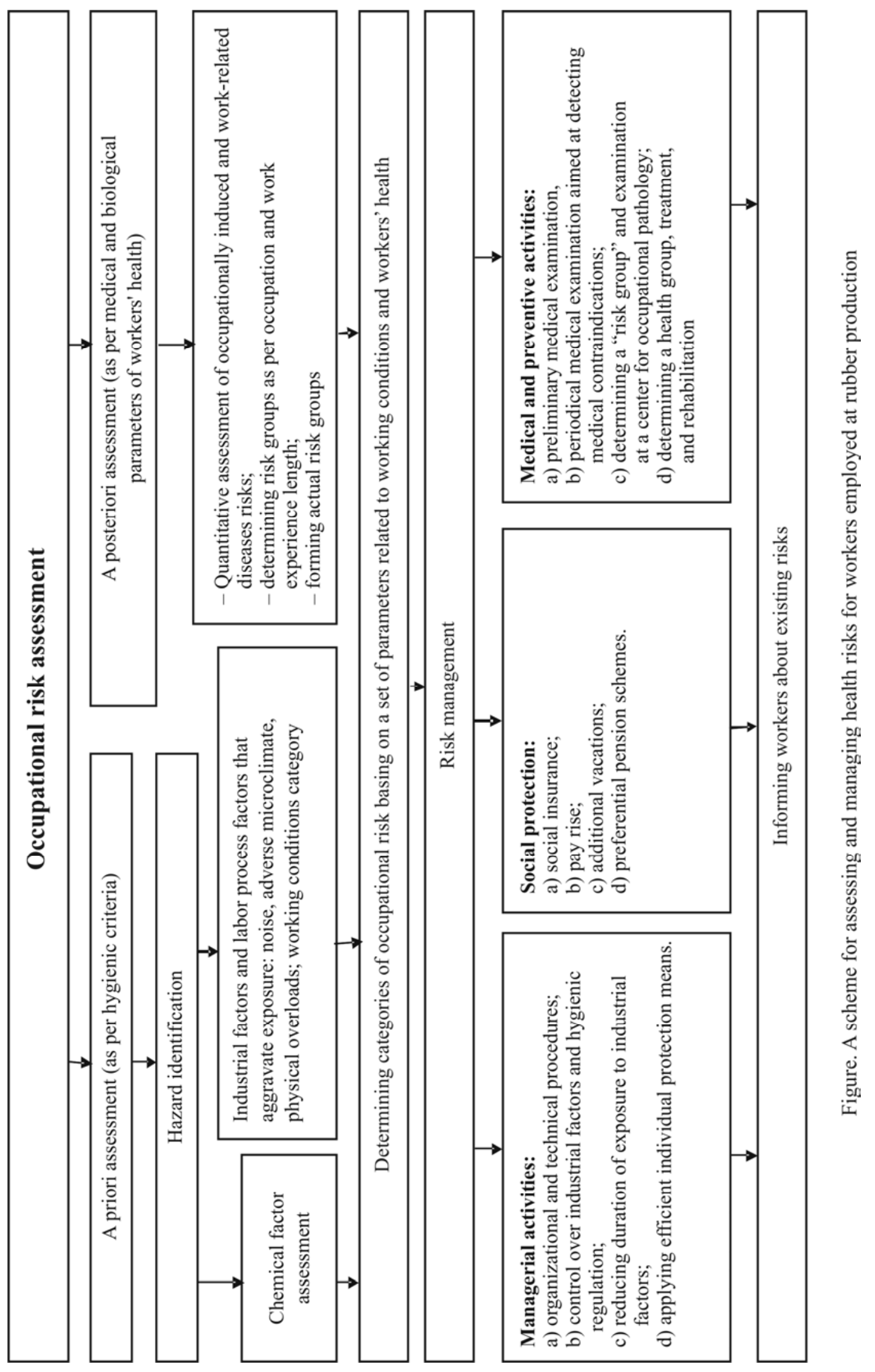




\section{Conclusions.}

1. We determined that there were several hazardous industrial factors and labor process factors at rubber production; they were hazardous chemicals, in-plant noise, adverse microclimate, and physical overloads. Overall assessment of working conditions for workers employed at rubber production ranked them as belonging to 3.2 hazard category.

2. Working conditions existing at up-todate rubber productions directly induce occupational diseases and are potentially hazardous for workers' health.

Gluers ran high risks of occupational diseases; spreading operators and vulcanizers, average risk. Total occupational morbidity index corresponded to high occupational risk.

3. We detected cause-and-effect relations between working conditions and frequency of specific chronic non-communicable diseases: there was significant occupational conditionality of disorders in the vegetative nervous system as per segmental type with sensory disorders in hands among gluers; hand polyneuropathy, facioscapulohumeral periathrosis, epicondylitis, and radiculopathy of skin and subcutaneous tissues among spreading operators.

4. A program for managing risks for workers' health was developed and implemented basing on occupational risk categories; the program included managerial and medical and preventive activities as well as social support and protection.

Funding. The research was not granted any sponsor support.

Conflict of interests. The authors declare there is no any conflict of interests.

\section{References}

1. Valeeva E.T., Karimova L.K., Mavrina L.N., Muldasheva N.A. Occupation al health risk for chemical workers. Gigiena truda, 2016, no. 12, pp. 19-21 (in Russian).

2. ValeevaE.T., BakirovA.B., KarimovaL.K. Occupational Risks for Chemical Workers' Health. Vestnik Rossiiskogo gosudarstvennogo universiteta, 2013, no. 5-6, pp. 124-128 (in Russian).

3. Valeeva E.T., Karimova L.K., Gimranova G.G. Faktory i pokazateli professional'nogo riska na sovremennykh neftekhimicheskikh predpriyatiyakh Respubliki Bashkortostan [Factors and parameters of occupational risks occurring at contemporary petrochemical productions in Bashkortostan]. Sovremennye problemy meditsiny truda: materially Vserossiiskoi nauchno-prakticheskoi konferentsii s mezhdunarodnym uchastiem, posvyashchennoi 50-letiyu obrazovaniya UfNII meditsina truda i ekologii cheloveka. Ufa, 2005, pp. 82-87 (in Russian).

4. Khamidulina Kh.Kh. Modern chemical factors' risk and impact management international requirements and their implementation in the system of state sanitary-epidemiologic control. Health Risk Analysis, 2014, no. 2, pp. 14-18. DOI: 10.21668/health.risk/2014.2.02.eng.

5. Babanov S.A., Budash D.S., Baikova A.G., Baraeva R.A. Periodic medical examinations and occupational selection in industrial medicine. Zdorov'e naseleniya i sreda obitaniya, 2018, vol. 302, no. 5, pp. 48-53 (in Russian).

6. Barg A.O., Lebedeva-Nesevrya N.A. Risk communication in analysis of occupational health risk for industrial workers. Meditsina truda i promyshlennaya ekologiya, 2015, no. 8, pp. 28-33 (in Russian).

7. Workers' health: global plan of action. World Health Organization, 2007. Available at: https://www.who.int/occupational_health/publications/global_plan/ru/ (01.10.2017) (in Russian).

8. Popova A.Yu. Strategic priorities of the Russian Federation in the field of ecology from the position of preservation of health of the nation. Zdorov'e naseleniya i sreda obitaniya, 2014, vol. 251, no. 2, pp. 4-7 (in Russian).

9. Babanov S., Strizhakov L., Budash D., Baikova A. Epidemiological survey strategy and risk assessment in occupational medicine. Vrach, 2018, vol. 29, no. 7, pp. 13-19 (in Russian).

10. DenisovE.I. Professional'nyi risk i profzabolevaniya [Occupational risk and occupational diseases]. Okhrana truda i sotsial'noes trakhovanie, 1999, no. 6, pp. 61-66 (in Russian).

11. Zheglova A.V. Metodicheskie podkhody k otsenke professional'nogo riska dlya zdorov'ya rabotayushchikh $\mathrm{v}$ neblagopriyatnykh usloviyakh truda [Methodical approaches to assessing occupational health risks for workers exposed to adverse working conditions]. Zdravookhranenie Rossiiskoi Federatsii, 2008, no. 1, pp. 46-47 (in Russian). 
12. Eliovich I.G., Mel'tser A.V., Yakubova I.Sh., Alloyarov P.R., Istorik O.A., Pankina E.N., Zhirnov A.Yu. Improvement of socio-hygienic monitoring at worker's occupational conditions with the use of production control. Gigiena i sanitariya, 2017, vol. 96, no. 4, pp. 339-343 (in Russian).

13. Izmerov N.F. Occupational assessment and management are the basis of prophylaxis in occupational medicine. Gigiena i sanitariya, 2006, no. 5, pp. 14-16 (in Russian).

14. Izmerov N.F., Denisov E.I., Molodkina N.N. Problema otsenki professional'nogo riska: itogi i perspektivy [Issues related to occupational risks assessment: results and prospects]. Byulleten' nauchnogosoveta «Mediko-ekologicheskie problemy zdorov'ya rabotayushchikh», 2004, no. 1, pp. 13-15 (in Russian).

15. Yang J., Bai W.N., Niu P., Tian L., Gao A. Aberrant hypomethylated STAT3 was identified as a biomarker of chronic benzene poisoning through integrating DNA methylation and mRNA expression data. Experimental and Molecular Pathology, 2014, vol. 96, no. 3, pp. 346-353. DOI: 10.1016/j.yexmp.2014.02.013

16. Kerzic P.J.,Liu W.S., Pan M.T., Fu H., Zhou Y., Schnatter A.R., IronsR.D. Analysis of hydroquinone and catechol in peripheral blood of benzene-exposed workers. Chemico-Biological Interactions, 2010, vol. 19, no. 184, pp. 182-188. DOI: 10.1016/j.cbi.2009.12.010

17. Rizzo M., Giannetto C., Longo F., Piccione G., Arfuso F., Giudice E., Di Pietro S. Cortisol levels and leukocyte population values in transported and exercised horses after acupuncture needle stimulation. Journal of Veterinary Behavior: Clinical Applications and Research, 2017, no. 18, pp. 56-61. DOI: 10.1016/j.jveb.2016.12.006

18. Wen H., Yuan L., Wei C., Zhao Y., Qian Y., Ma P., Ding S., Yang X., Wang X.Effects of combined exposure to formaldehyde and benzene on immune cells in the blood and spleen in Balb/c mice. Environmental Toxicology and Pharmacology, 2016, no. 45, pp. 265-273. DOI: 10.1016/j.etap.2016.05.007

19. Schulte P. Challenges for risk assessors. Hum. and Ecol. Risk Assess, 2003, vol. 9, no. 1, pp. 439-445. DOI: 10.1080/713609874

20. Khoruzhaya O.G., Gorblyanskii Yu.Yu., Piktushanskaya T.E. Indicators and criteria of the assessment of quality of medical examinations of workers. Meditsina truda i promyshlennaya ekologiya, 2015, no. 11, pp. 33-37 (in Russian).

Valeeva E.T., Karimova L.K., Galimova R.R., Muldasheva N.A., Distanova A.A. Assessment of occupational health risk for workers employed at contemporary rubber production. Health Risk Analysis, 2020, no. 1, pp. 59-67. DOI: 10.21668/health.risk/2020.1.06.eng

Received: 16.12.2019

Accepted: 09.02.2020

Published: 30.03 .2020 